\title{
Low 25-hydroxyvitamin D concentrations may explain the link between breast cancer risk and shift work
}

\author{
William B. Grant
}

Received: 20 October 2014 / Accepted: 21 November 2014 / Published online: 29 November 2014

(C) Springer-Verlag Berlin Heidelberg 2014

To the Editor,

The recent meta-analysis by He et al. (2014) found shift work significantly correlated with risk of breast cancer (BrCA). The mechanism proposed to explain this finding was disruption of the circadian rhythm. However, just how this mechanism might work was not discussed.

Overlooked in this paper was any discussion of an alternate hypothesis to explain the findings: lower 25-hydroxyvitamin $\mathrm{D}[25(\mathrm{OH}) \mathrm{D}]$ concentrations due to sleeping during daytime. This hypothesis was proposed in a letter to the editor (Grant 2013) to explain the finding regarding cancer risk related to night shift work by men in Canada (Parent et al. 2012). The evidence for this hypothesis includes the following: Sunlight is the most important source of vitamin D for most people (Hyppönen and Power 2007); outdoor occupation is a significant risk reduction factor for many types of cancer including female breast cancer (Grant 2012); night work is a significant risk reduction factor for skin cancer including melanoma for women (Schernhammer et al. 2011); and solar ultraviolet irradiance is the most important risk factor for skin cancer and melanoma (Wu et al. 2014).

There are many health benefits of UVB and vitamin D (Hossein-Nezhad and Holick 2013), and the optimal $25(\mathrm{OH}) \mathrm{D}$ concentration seems to be $100-130 \mathrm{nmol} / \mathrm{L}$ (Heaney 2014). Thus, those who work night shifts should seek to increase $25(\mathrm{OH}) \mathrm{D}$ concentrations by solar UVB near solar noon or vitamin D supplements.

\section{References}

Grant WB (2012) Role of solar UV irradiance and smoking in cancer as inferred from cancer incidence rates by occupation in Nordic countries. Dermatoendocrinol 4(2):203-211

Grant WB (2013) Re: "Night work and the risk of cancer among men"; author reply. Am J Epidemiol 177:1165-1166

He C, Anand ST, Ebell MH, Vena JE, Robb SW (2014) Circadian disrupting exposures and breast cancer risk: a meta-analysis. Int Arch Occup Environ Health [Epub ahead of print]

Heaney RP (2014) Toward a physiological referent for the vitamin D requirement. J Endocrinol Invest [Epub ahead of print]

Hossein-Nezhad A, Holick MF (2013) Vitamin D for health: a global perspective. Mayo Clin Proc 88(7):720-755

Hyppönen E, Power C (2007) Hypovitaminosis D in British adults at age $45 \mathrm{y}$ : nationwide cohort study of dietary and lifestyle predictors. Am J Clin Nutr 85(3):860-868

Parent MÉ, El-Zein M, Rousseau MC, Pintos J, Siemiatycki J (2012) Night work and the risk of cancer among men. Am J Epidemiol 176(9):751-759

Schernhammer ES, Razavi P, Li TY, Qureshi AA, Han J (2011) Rotating night shifts and risk of skin cancer in the nurses' health study. J Natl Cancer Inst 103(7):602-606

Wu S, Han J, Laden F, Qureshi AA (2014) Long-term ultraviolet flux, other potential risk factors, and skin cancer risk: a cohort study. Cancer Epidemiol Biomark Prev 23(6):1080-1089
W. B. Grant $(\bowtie)$

Sunlight, Nutrition, and Health Research Center, P.O. Box

641603, San Francisco, CA 94164-1603, USA

e-mail: wbgrant@infionline.net

URL: http://www.sunarc.org 